\title{
ORIGINAL ARTICLE \\ Modification of atmospheric sand-associated bacterial communities during Asian sandstorms in China and South Korea
}

\author{
$S \mathrm{An}^{1}, \mathrm{HH}$ Sin and MS DuBow
}

The transport of desert soil into the atmosphere during desert sandstorms can affect the Earth's climate and environmental health. Asian desert sandstorms occur almost every year during the Spring, as the atmosphere in the Northern hemisphere warms. It is conceivable that these Asian desert sandstorms may transport microbes from deserts, such as the Gobi and Taklamaken deserts, over long distances in China, east Asia and the Pacific. In this study, we examined local atmospheric sand particle-associated bacterial populations collected in the absence (sterile sand exposed for $24 \mathrm{~h}$ to the air in the absence of a sandstorm) and presence of sandstorms in five Asian cities. We used pyrosequencing of PCR-amplified 16S rDNA genes from sand-extracted total DNA to overcome cultivation limitations of bacterial enumeration. We found that $>90 \%$ of the control and sandstorm sequences could be classified as representing bacteria belonging to four phyla: Proteobacteria, Bacteriodetes, Actinobacteria and Firmicutes. The sand-associated bacterial populations in sandstorm samples were distinct from sandassociated bacteria in the absence of a sandstorm. Members of the phylum Proteobacteria were found to significantly increase in sandstorm samples $(P=0.01)$. Principal component analyses showed that the sand-associated bacterial populations were best clustered by sampling year, rather than location. DNA sequences representing bacteria belonging to several genera (including putative human pathogens) were observed to increase in sand-associated samples from sandstorms, whereas others were found to decrease, when comparing sand-associated bacterial populations versus those in control samples, suggesting human/ environmental implications of sandstorm events.

Heredity (2015) 114, 460-467; doi:10.1038/hdy.2014.102; published online 12 November 2014

\section{INTRODUCTION}

Asian sandstorms can spread $\sim 4-8 \times 10^{11} \mathrm{~kg}$ of sand to other parts of the world every year (Bishop et al., 2002). It is likely that the arrival of desert bacteria on the sand may modify the local atmospheric bacterial population engendering possible human and environmental health effects (Cao et al., 2014). Studies of Asian sandstorm particleassociated bacterial populations may allow the identification of potential microbiological risks to human and environmental health that the sandstorms may bring. The largest sources on Earth for desert sandstorms are the Sahara desert in North Africa and the Gobi plus Taklamaken deserts in Asia (Griffin, 2007). With high-energy winds, the desert sand can be transported over long distances, which makes these sandstorms a global phenomenon. African sandstorms from the Sahara desert and Sahel region can affect the air quality of the Middle East, Europe, Asia, the Caribbean and the Americas (Gorbushina et al., 2007). Asian sandstorms from the Gobi, Taklamaken and Badain Jaran deserts can cross eastern Asia, the Pacific Ocean and arrive in North America (Bishop et al., 2002). Desert dust is an important part of the atmospheric aerosol in some regions, and dust clouds transported over long distances can make substantial contributions to the aerosol content of the atmosphere in distant regions. For example, $\sim 50 \%$ of the particles in Florida's atmosphere, each summer, are postulated to be African in origin (Prospero, 1999; Prospero and Lamb, 2003).
The potential for bacteria and other microorganisms to be transported over long distances through the air is being increasingly examined (Burrows et al., 2009). The average residence time of microorganisms in the atmosphere can range from days to weeks, long enough for cells to travel between continents. During air transport of microorganisms, they are exposed to many environmental stresses, including ultraviolet radiation, desiccation and low $\mathrm{pH}$ within cloud water (Burrows et al., 2009). Microorganisms, such as bacteria, in aerosols are often found to be attached to mineral dust or other larger aerosol particles (Iwasaka et al., 2009). It has been hypothesized that bacteria attached to larger particles are more likely to retain viability, perhaps because the particle microenvironment protects them from these environmental stresses (Iwasaka et al., 2009). Though most wind-borne bacteria are typically transported $<1 \mathrm{~km}$ from their source, dust-associated bacteria can be transported over $5000 \mathrm{~km}$ (Griffin et al., 2003; Iwasaka et al., 2009). The arrival of dust events increases the local concentration of particulate matter $\left(\mathrm{PM}_{10}\right)$ (particles $<10 \mu \mathrm{m}$ in size) and $\mathrm{PM}_{2.5}$ (particles $<2.5 \mu \mathrm{m}$ in size) (Bell et al., 2008; Cao et al., 2014). Of particular concern are that these particles can penetrate into the lungs and the subepithelial environment (Griffin, 2007), thus leading to an increase of dust-associated potential allergen and pathogen exposure in the lungs. 
Asian dust, also called KOSA, is a meteorological phenomenon occuring mainly during the Spring, with large environmental effects, especially for eastern Asia, China, the Korean peninsula and Japan. Asian sandstorms are considered as air pollution that can affect environmental quality and may also pose a potential risk for public and environmental health, as large numbers of microorganisms may be transported along with the dust (Yang et al., 2005; Griffin, 2007; Lee et al., 2007). The transport of microbes by Asian dust has been reported (Shinn et al., 2003; Lee et al., 2009), and the presence of pathogens and allergens, with the potential to affect the health of downwind populations and ecosystems, was also revealed (Kellogg and Griffin, 2006). More than $2 \times 10^{13}$ to $4 \times 10^{16}$ bacterial cells km $\mathrm{km}^{-2}$ per month were estimated to be transported to Beijing by Asian dust (Nishimura et al., 2010). To identify bacteria in Asian dust, classical cultivation methods have been used to compare the differences in atmospheric colony-forming units (CFU) between normal and Asian dust days (Choi et al., 1997; Iwasaka et al., 2009). Choi et al. (1997) showed a 4.3 -fold increase in the number of bacterial CFU during an Asian dust storm in Daejon (South Korea), whereas Jeon et al. (2010) indicated that the cultivable atmospheric bacterial population levels during sandstorms showed significant positive correlations with total suspended particles and $\mathrm{PM}_{10}$. As a minority of environmental bacteria can be cultured under standard laboratory conditions (Amann et al., 1995), the observed CFU counts likely represent a fraction of the actual bacterial diversity. Cultureindependent methods, such as denaturing gradient gel electrophoresis and terminal restriction fragment length polymorphism, are being increasingly used in these studies (Lee et al., 2009; Jeon et al., 2010; Nishimura et al., 2010). Using terminal restriction fragment length polymorphism analysis, Nishimura et al. (2010) showed that the bacterial community structures in Asian dust samples differed greatly according to the scale of the dust event. The bacterial communities from major dust events were similar to those from an arid region of China (Nishimura et al., 2010). Jeon et al. (2010) demonstrated that the ambient air bacterial community structure was changed during Asian dust events in Seoul (South Korea) by comparing PCRamplified 16S rDNA gene fragments using denaturing gradient gel electrophoresis-band patterns and differences in PCR-amplified 16S rDNA clone libraries between Asian dust and non-dust days (Jeon et al., 2010). As particle-associated microorganisms can survive long distance transport (Griffin et al., 2003; Iwasaka et al., 2009), a study of sandstorm-associated microorganisms may illuminate the influence of long-range bacterial transport on downwind communities.

Here, we focused on sand-associated bacterial populations in five Asian cities in China and South Korea. In order to obtain a more complete view of sand-associated bacterial communities in these Asian sandstorm events, we used DNA pyrosequencing of $16 \mathrm{~S}$ rDNA amplicons from total DNA extracted from sand to explore the local atmospheric bacterial composition in the presence of Asian sandstorm events. As controls, we examined local atmospheric bacterial populations that could adsorb to sterile sand, after $24 \mathrm{~h}$ exposure at the same locales and years, but in the absence of a sandstorm event. Sequence level comparisons were used to examine the different sandstorm and control samples, and members of several bacterial genera were found to decrease in proportion, whereas others were found to increase in proportion, during sandstorms at all sites examined, including genera that have been reported to be common in hot desert ecosystems: Pontibacter, Pedobacter, Lysobacter, Planococcus and members of the potential human pathogen Massilia.

\section{MATERIALS AND METHODS}

\section{Study sites and sampling}

Sampling was performed in five Asian cities over a span of 3 years. Two cities (Beijing and Taiyuan) are located in China, whereas the other three (Seoul, Gwangju and Incheon) are located in South Korea (Figure 1). Two timesautoclaved Gobi desert sand samples (25 g) (An et al., 2013) were placed on sterile plastic sheets on the roof of a building in each city for $24 \mathrm{~h}$ in the absence of an Asian sandstorm to act as local atmospheric sand-associated bacteria controls (control samples). Sand from sandstorms was collected using sterile plastic sheets to collect settled sand at the same locations. The sampling dates and GPS site references are listed in Table 1. Sandstorms were identified by continuous monitoring of the Korean Meteorological Administration web site dedicated to identifying and following Asian dust storms: http://web.kma.go.kr/ eng/weather/asiandust/intro.jsp

We sampled during periods when the $\mathrm{PM}_{10}$ levels were predicted to exceed $250 \mu \mathrm{g} \mathrm{m}^{-3}$ at the sampling sites, generally found to last for $\sim 24 \mathrm{~h}$. Samples in 2009 were taken in August, whereas samples in 2010 and 2011 were collected from February to May. Samples were named by their first letter of the sampling city (B: Beijing; S: Seoul; G: Gwangju; T: Taiyuan and I: Incheon); C or S after

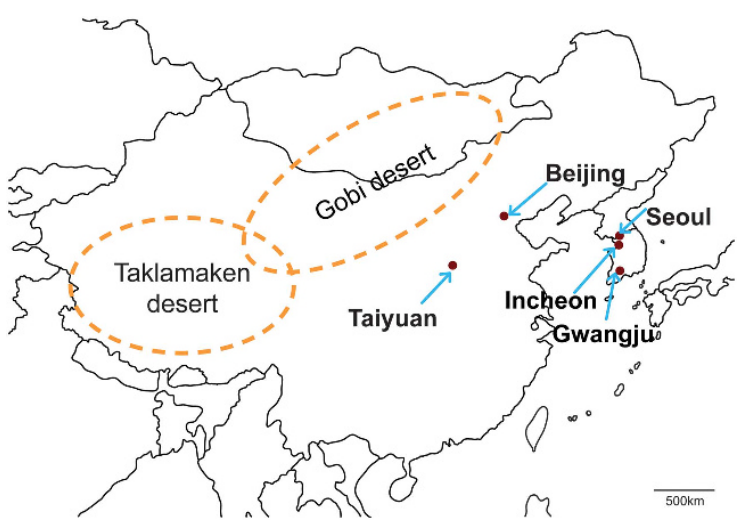

Figure 1 The location of the sampling site cities in China and South Korea, and the two major Asian deserts (Gobi and Taklamaken). The edges of the deserts are indicated by dashed yellow lines.

Table 1 Dates and location of sampling

\begin{tabular}{|c|c|c|c|}
\hline Sample & Date & $\begin{array}{l}\text { Sandstorm or } \\
\text { control }\end{array}$ & GPS site coordinates \\
\hline BC2009 & 28/08/2009 & Control & $39^{\circ} 58^{\prime} 45^{\prime \prime} \mathrm{N} 116^{\circ} 18^{\prime} 57^{\prime \prime} \mathrm{E}$ \\
\hline SC2009 & $18 / 08 / 2009$ & Control & $37^{\circ} 33^{\prime} 59^{\prime \prime} \mathrm{N} 126^{\circ} 18^{\prime} 57^{\prime \prime} \mathrm{E}$ \\
\hline GC2009 & 21/08/2009 & Control & $35^{\circ} 09^{\prime} 40^{\prime \prime} \mathrm{N} 126^{\circ} 56^{\prime} 05^{\prime \prime} \mathrm{E}$ \\
\hline BC2010 & 27/02/2010 & Control & $39^{\circ} 58^{\prime} 45^{\prime \prime} \mathrm{N} 16^{\circ} 18^{\prime} 57^{\prime \prime} \mathrm{E}$ \\
\hline BS2010 & 20/05/2010 & Sandstorm & $39^{\circ} 58^{\prime} 45^{\prime \prime} \mathrm{N} 16^{\circ} 18^{\prime} 57^{\prime \prime} \mathrm{E}$ \\
\hline GC2010 & 08/03/2010 & Control & $35^{\circ} 09^{\prime} 40^{\prime \prime} \mathrm{N} 126^{\circ} 56^{\prime} 05^{\prime \prime} \mathrm{E}$ \\
\hline GS2010 & 19/03/2010 & Sandstorm & $35^{\circ} 09^{\prime} 40^{\prime \prime} \mathrm{N} 126^{\circ} 56^{\prime} 05^{\prime \prime} \mathrm{E}$ \\
\hline BC2011 & 07/02/2011 & Control & $39^{\circ} 58^{\prime} 45^{\prime \prime} \mathrm{N} 116^{\circ} 18^{\prime} 57^{\prime \prime} \mathrm{E}$ \\
\hline BS2011a & 18/03/2011 & Sandstorm & $39^{\circ} 58^{\prime} 45^{\prime \prime} \mathrm{N} 116^{\circ} 18^{\prime} 57^{\prime \prime} \mathrm{E}$ \\
\hline BS2011b & 01/05/2011 & Sandstorm & $39^{\circ} 58^{\prime} 45^{\prime \prime} \mathrm{N} 116^{\circ} 18^{\prime} 57^{\prime \prime} \mathrm{E}$ \\
\hline TC2011 & 07/02/2011 & Control & $37^{\circ} 50^{\prime} 02^{\prime \prime} \mathrm{N} 112^{\circ} 32^{\prime} 34^{\prime \prime} \mathrm{E}$ \\
\hline TS2011a & $18 / 03 / 2011$ & Sandstorm & $37^{\circ} 50^{\prime} 02^{\prime \prime} \mathrm{N} 112^{\circ} 32^{\prime} 34^{\prime \prime} \mathrm{E}$ \\
\hline TS2011b & 01/05/2011 & Sandstorm & $37^{\circ} 50^{\prime} 02^{\prime \prime} \mathrm{N} 112^{\circ} 32^{\prime} 34^{\prime \prime} \mathrm{E}$ \\
\hline GC2011 & $17 / 05 / 2011$ & Control & $35^{\circ} 09^{\prime} 40^{\prime \prime} \mathrm{N} 126^{\circ} 56^{\prime} 05^{\prime \prime} \mathrm{E}$ \\
\hline GS2011 & $13 / 05 / 2011$ & Sandstorm & $35^{\circ} 09^{\prime} 40^{\prime \prime} \mathrm{N} 126^{\circ} 56^{\prime} 05^{\prime \prime} \mathrm{E}$ \\
\hline IC2011 & $17 / 05 / 2011$ & Control & $37^{\circ} 27^{\prime} 22^{\prime \prime} \mathrm{N} 126^{\circ} 42^{\prime} 19^{\prime \prime} \mathrm{E}$ \\
\hline IS2011a & 01/05/2011 & Sandstorm & $37^{\circ} 27^{\prime} 22^{\prime \prime} \mathrm{N} 126^{\circ} 42^{\prime} 19^{\prime \prime} \mathrm{E}$ \\
\hline IS2011b & 03/05/2011 & Sandstorm & $37^{\circ} 27^{\prime} 22^{\prime \prime} \mathrm{N} 126^{\circ} 42^{\prime} 19^{\prime \prime} \mathrm{E}$ \\
\hline
\end{tabular}


the first letter refers to control (C) or sandstorm (S), and these terminate with their sampling year. The $\mathrm{a}$ or $\mathrm{b}$ after a sampling year were added when more than one sandstorm sample was taken in the same year. After collection, samples were treated as previously described (An et al., 2013), as described in detail in the following sections. Briefly, sand samples were rehydrated, total DNA was extracted, 16S rDNA genes were barcode amplified using two different thermostable DNA polymerases in several tubes to minimize PCR bias and then the DNAs were gel purified, pooled and subjected to DNA pyrosequencing.

\section{DNA extraction}

Total DNA was extracted from each sand sample as previously described (An et al., 2013). From 0.5 to $2 \mathrm{~g}$ of sand were incubated at $30^{\circ} \mathrm{C}$ with shaking for $1 \mathrm{~h}$ after addition of $1 \mathrm{ml} \mathrm{1/4}$ tryptic soy broth to both rehydrate the bacteria and minimize nutrient shock. Then, $13.5 \mathrm{ml}$ extraction buffer $(100 \mathrm{~mm}$ Tris$\mathrm{HCl}$ pH 8, 100 mm Na-EDTA pH 8, 100 mm Na $2 \mathrm{HPO}_{4}, 1.5 \mathrm{M} \mathrm{NaCl}, 1 \%$ (w/v) cetyltrimethyl ammonium bromide, containing $74 \mu \mathrm{g} \mathrm{ml}^{-1}$ predigested Pronase plus $6.7 \mu \mathrm{g} \mathrm{ml}^{-1}$ RNAse A, followed by a $2-\mathrm{h}$ incubation at $37^{\circ} \mathrm{C}$ with mild shaking. Following this, $1.5 \mathrm{ml}$ of a $20 \%(\mathrm{w} / \mathrm{v})$ sodium dodecyl sulfate solution was added and incubation continued at $65^{\circ} \mathrm{C}$ for a further $2 \mathrm{~h}$. The supernatant fluid was collected after a 10-min centrifugation at $6000 \mathrm{~g}$ at room temperature. The pellet was extracted one more time with $4.5 \mathrm{ml}$ extraction buffer plus $2 \%$ $(\mathrm{w} / \mathrm{v})$ sodium dodecyl sulfate, mixed by vortexing for $10 \mathrm{~s}$, followed by incubation for $10 \mathrm{~min}$ at $65^{\circ} \mathrm{C}$ and, after centrifugation, the supernatant fluids were pooled. The nucleic acids were extracted by the addition of an equal volume of chloroform/isoamyl alcohol (24:1) to the pooled supernatant fluids, and precipitated by the addition of 0.6 volumes of isopropanol for $1 \mathrm{~h}$ at room temperature, followed by centrifugation at $16000 \mathrm{~g}$ for $20 \mathrm{~min}$ at $20^{\circ} \mathrm{C}$. The DNA pellet was washed with $70 \%$ ethanol, followed by centrifugation at 16 $000 \mathrm{~g}$ for $5 \mathrm{~min}$ at $20^{\circ} \mathrm{C}$. The DNA pellets were then air-dried and resuspended in $50 \mu \mathrm{l} 1 / 10$ TE (Tris-EDTA, $10 \mathrm{~mm}$ Tris-HCl (pH 7.5), 1 mm EDTA) buffer (Tolias and DuBow, 1986) at $4{ }^{\circ} \mathrm{C}$ overnight and stored at $-20^{\circ} \mathrm{C}$ until use.

\section{Bacterial tag-encoded FLX amplicon pyrosequencing (bTEFAP) PCR}

An aliquot of extracted total DNA was adjusted to a final DNA concentration of $15 \mathrm{ng} \mathrm{ll}^{-1}$ in 1/10 TE buffer using a NanoVue spectrophotometer (GE Healthcare, Buckinghamshire, UK), and verified by ethidium bromide fluorescence after electrophoresis through a $1 \%$ agarose gel in TAE $(2 \mathrm{~mm}$ Trisacetate $\mathrm{pH} 8,5 \mathrm{~mm}$ Na-EDTA) buffer. Then, multiple $50 \mu \mathrm{l}$ PCR reactions were performed using the universal $16 \mathrm{~S}$ rDNA bacterial primers: 27F (Axxxxxx AGAGTTTGATCMTGGCTCAG) and 357R (BxxxxxxCTGCTGCCTYCCGTA), where $A$ and $B$ represent the adapters $\mathrm{A}$ and $\mathrm{B}$ for pyrosequencing using the Gold pyrosequencing reaction (GS-FLX, Roche/454 Life Sciences, CT, USA) for samples from 2009 to 2010. For the 2011 samples, primers 27F (AGAGTTT GATCMTGGCTCAG) and 517R (BxxxxxxxxxxWTTACCGCGGCTGCTGG) were used, where $A$ and $B$ represent the adapters $\mathrm{A}$ and $\mathrm{B}$ for pyrosequencing using the Titanium pyrosequencing reaction (GS-FLX Titanium, Roche/454 Life

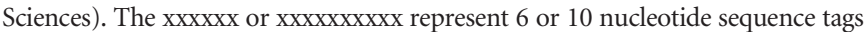
designed for sample identification barcoding (Hamady et al., 2008). PCR amplification conditions were adapted for the use of five different thermostable DNA polymerases: I, Phusion High-Fidelity DNA Polymerase (Finnzymes, Espoo, Finland): $98^{\circ} \mathrm{C}$ for 2 min followed by 25 cycles of $98^{\circ} \mathrm{C}$ for $30 \mathrm{~s}, 48$ or $54{ }^{\circ} \mathrm{C}$ for $20 \mathrm{~s}$ and $72^{\circ} \mathrm{C}$ for $12 \mathrm{~s}$, and a final elongation step at $72{ }^{\circ} \mathrm{C}$ for $5 \mathrm{~min}$; II, Pfu DNA polymerase (Fermentas, ON, Canada): $95^{\circ} \mathrm{C}$ for $3 \mathrm{~min}$ followed by 35 cycles of $95^{\circ} \mathrm{C}$ for $30 \mathrm{~s}, 48$ or $54^{\circ} \mathrm{C}$ for $30 \mathrm{~s}$ and $72^{\circ} \mathrm{C}$ for $48 \mathrm{~s}$, and a final elongation step at $72^{\circ} \mathrm{C}$ for $5 \mathrm{~min}$; III, High-Fidelity PCR Enzyme Mix (Fermentas): $94^{\circ} \mathrm{C}$ for $3 \mathrm{~min}$ followed by 30 cycles of $94^{\circ} \mathrm{C}$ for $30 \mathrm{~s}, 48$ or $54^{\circ} \mathrm{C}$ for $30 \mathrm{~s}$ and $72^{\circ} \mathrm{C}$ for $24 \mathrm{~s}$, and a final elongation step at $72^{\circ} \mathrm{C}$ for $5 \mathrm{~min}$; IV, AccuPOL DNA Polymerase (Ampliqon, Herlev, Denmark): $96^{\circ} \mathrm{C}$ for $2 \mathrm{~min}$ followed by $35-43$ cycles of $96^{\circ} \mathrm{C}$ for $45 \mathrm{~s}, 49^{\circ} \mathrm{C}$ for $45 \mathrm{~s}$ and $72^{\circ} \mathrm{C}$ for $1 \mathrm{~min}$ $12 \mathrm{~s}$, and a final elongation step at $72^{\circ} \mathrm{C}$ for $10 \mathrm{~min}$; V, iProof High-Fidelity DNA Polymerase (Bio-Rad, Hercules, CA, USA): $98^{\circ} \mathrm{C}$ for $30 \mathrm{~s}$ followed by 30 cycles of $98^{\circ} \mathrm{C}$ for $10 \mathrm{~s}, 57^{\circ} \mathrm{C}$ for $30 \mathrm{~s}$ and $72^{\circ} \mathrm{C}$ for $18 \mathrm{~s}$, and a final elongation step at $72^{\circ} \mathrm{C}$ for $5 \mathrm{~min}$. Each $50 \mu \mathrm{l}$ PCR reaction contained $15 \mathrm{ng}$ DNA, $0.1 \mu \mathrm{M}$ of each primer (Sigma-Aldrich, St Louis, MO, USA), $0.2 \mathrm{~mm}$ dNTP mix
(Fermentas), 1.25 units polymerase for I and II, 2 units polymerase for III, 2.5 units polymerase for IV and 1 unit polymerase for $\mathbf{V}$ using the buffers supplied with each polymerase. Each DNA sample was subjected to 5-10 PCR reactions per thermostable DNA polymerase, and two different polymerases were used per sample to minimize PCR bias. The resultant PCR products were pooled and loaded on a $1 \%$ agarose gel in TAE buffer (An et al., 2013). After electrophoreses and DNA visualization by ethidium bromide staining and long-wave ultraviolet light illumination, the $16 \mathrm{~S}$ amplified DNA fragmentcontaining regions were cut from the gel and purified using the NucleoSpin Extract II kit (Macherey-Nagel, North Rhine-Westphalia, Germany) according to the manufacturers' instructions. Fifty nanograms of PCR products from each sample were mixed for pyrosequencing.

\section{bTEFAP FLX pyrosequencing}

Pyrosequencing was performed using a Roche/454 FLX Pyrosequencer (Microsynth AG, Balgach, Switzerland). The sequences obtained for each sample were grouped according to the tag used, and the average sequence was found to be 227 nucleotides in length for those using the Gold reaction and 503 nucleotides in length for the samples using the Titanium reaction, after removal of the tags.

\section{bTEFAP sequence processing pipeline and data analyses}

The sequences were selected by their length ( $>150$ bases) and their quality score $(90 \%$ of nucleotides with a quality score $>25)$ using the Greengenes website (http://greengenes.lbl.gov/cgi-bin/nph-index.cgi). Then, sequences with more than two errors in the primer or more than one ambiguous base were removed using the RDP pyrosequencing pipeline (http://pyro.cme.msu.edu/ index.jsp).

The remaining sequences were then classified to the genus level using RDPII-naive Bayesian classifier (Liu et al., 2007; Wang et al., 2007) with the confidence threshold set to $50 \%$ for Gold reaction samples and $80 \%$ for Titanium reaction samples. The sequences classified as chloroplast were eliminated using 'FASTA Sequence Selection' in RDP's pyro site. The non classified sequences were used for a further BLAST against the Genbank database to detect potential mitochondrial DNA sequences. In order to compare the estimations for bacterial population richness and diversity, we also normalized the sequence numbers for each sample by randomly selecting 3400 sequences from each sample from the fasta file using a perl script called 'selector.pl' in Pangea (Giongo et al., 2010). The Chaol estimator and Shannon indices were calculated on the RDPII-pyro site, whereas the Bray-Curtis index was calculated using SPADE (http://chao.stat.nthu.edu.tw) to build the unweighted pair group method with arithmetic mean (UPGMA) clustering tree. The similarity level among the different operational taxonomic units (OTUs) was fixed at $97 \%$. We calculated the $P$-value of the chi-square test for the bacterial populations from each pair of samples using R software (http:// www.r-project.org/). Principal component analyses (PCA) on the relative proportion of phyla or OTUs among the samples were performed using the ade-4 package (Chessel et al., 2004) adapted in R. All sequence data have been deposited in the MG-RAST (http://metagenomics.anl.gov/metagenomics.cgi? page $=$ Home) database under numbers 4487160.3-4487161.3, 4487162.34487166.3, 4487168.3-4487172.3, 4487174.3-4487177.3, 4487179.3-4487181.3.

\section{RESULTS}

\section{DNA sequence quality assessment}

We collected nine different dust/sand samples, on sterile plastic sheets, that fell during Asian sandstorm events in five Asian cities (Beijing and Taiyuan in China; Gwangju, Incheon and Seoul in South Korea) in 2010 and 2011 (Figure 1). As controls, we prepared sterile sand from the Gobi desert and allowed local atmospheric bacteria (in the same locations used for sandstorm collections) to adhere to the sand, spread on sterile plastic sheets, for $24 \mathrm{~h}$ in the absence of a sandstorm (nine different samples from 2009 to 2011). After total DNA extraction from each of the collected sand samples, 16S rDNA PCR amplification and DNA pyrosequencing, a total of 507778 sequences were obtained. After quality control checks and sequence elimination using the 
Greengenes and RDPII pyrosequencing pipelines, followed by B2C2 chimera sequence removal, a total of 361748 sequences remained. The average sequence length after the quality control steps was $229 \mathrm{nt}$ for pyrosequencing Gold reactions and $373 \mathrm{nt}$ for the pyrosequencing Titanium reactions. Chloroplast sequences were detected (and removed) in 13 of 18 samples, with their proportion varying between 0.04 and $4.2 \%$. As mitochondrial $16 \mathrm{~S}$ rDNA sequences would be revealed as unclassified sequences using the RDP classifier, we examined the unclassified sequences in Genbank using BLAST and found that the proportion of mitochondrial DNA sequences represented $<0.01 \%$ of the sequences per sample.

Richness and diversity in sand-associated bacterial populations We observed that the detectable OTU numbers varied from 321 to 4026 per sample. Nonetheless, ChaoI estimations suggest that we were able to identify from 50 to $90 \%$ of the total OTU population (Table 2). In total, bacteria from 951 different genera were detected in our samples. As shown in Table 2, only the control samples from Gwangju (2010) and Incheon (2011) contained fewer than 1000 OTUs, as calculated using Chao1, though the Gwuangju 2010 sample had 3505 sequences, whereas the Incheon 2011 sample had 23466 sequences, a sevenfold difference. Normalizing the sequences to 3400 per sample did lower the estimated population richness (Chaol), whereas the Shannon diversity index remained relatively stable. It is interesting to note that during non-sandstorm event days, the samples from China displayed a significantly higher bacterial population richness (Chaol) than the samples from South Korea $(P=0.03)$. The bacterial OTU richness and diversity from the same sampling site varied among the different years, as well as between non-sandstorm controls versus sandstorm samples. No consistent trends were observed when comparing the richness and diversity between the control samples and sandstorm samples at each sampling site over the 3 years.
Sequence level comparisons and bacterial population composition Figure 2 shows the composition of the bacterial populations of the different samples at the phylum level. All the samples were dominated ( $90 \%$ of the sequences) by members belonging to four phyla: Proteobacteria, Bacteriodetes, Actinobacteria and Firmicutes, although no obvious (for example, control versus sandstorm) differences were discernible. In order to reveal any underlying tendencies in the composition of the different bacterial populations, a UPGMA clustering tree (Figure 3) was generated with the data of pairwise Bray-Curtis indices calculated using SPADE (sequence similarity level at 97\%). The 18 samples were found to contain distinct bacterial communities. Nonetheless, the control samples were found to be best clustered by sampling year, as were the sandstorm samples. As the temporal variability of air-borne bacteria has been previously reported (Bowers et al., 2012), PCA were performed only for samples from the same season, and only on samples from 2010 and 2011, as these have both sandstorm and control samples. PCA, using the sequence-normalized data, were generated using the ade- 4 package of $\mathrm{R}$ (Figure 4). We observed that samples were best able to be clustered by sampling year, rather than sampling condition (control versus sandstorm) or sampling site, as observed using UPGMA clustering (Figure 3). PCA at the phylum level explained close to half $(46.3 \%)$ of the total variance. The large difference observed between GS2010 and the other samples was due to the higher abundance of members belonging to the phyla Bacteroidetes, Cyanobacteria, Fibrobacteres, Deferribacteres, OD1 and WS3. The differences among samples from 2010 versus samples from 2011 at the OTU/species level were more difficult to discern. We observed that samples from 2010 contained more OTUs belonging to Delftia sp. and Acinetobacter sp., whereas samples from 2011 contained more OTUs belonging to Planococcus sp., Psychrobacter sp., Methylobacterium sp., Herbaspirillum sp., Rubellimicriobium sp. and Microvirga sp.

We were able to discern nine genera whose members increased in sandstorm samples versus the controls (Table 3), with the exception of the samples from Gwangju in 2011. The reason for this exception will

Table 2 Number of processed pyrosequencing sequences, OTU richness and diversity for each sample

\begin{tabular}{|c|c|c|c|c|c|c|c|c|}
\hline \multirow[t]{2}{*}{ Sample } & \multicolumn{5}{|c|}{ High-quality sequences } & \multicolumn{3}{|c|}{ Normalized sequences } \\
\hline & Number of sequences & OTUS & Chaol & $\%$ Coverage & Shannon index & OTUS & Chaol & Shannon index \\
\hline BC2009 & 10895 & 2353 & 3517 & 66.9 & 6.82 & 1179 & 2229 & 6.41 \\
\hline GC2009 & 4545 & 791 & 1203 & 65.8 & 5.37 & 683 & 1108 & 5.34 \\
\hline SC2009 & 8383 & 1315 & 2086 & 63.1 & 5.75 & 776 & 1381 & 5.59 \\
\hline BC2010 & 3386 & 603 & 1170 & 51.5 & 4.35 & 603 & 1170 & 4.35 \\
\hline GC2010 & 3505 & 321 & 474 & 67.7 & 2.90 & 315 & 473 & 2.90 \\
\hline BC2011 & 31959 & 3419 & 4247 & 80.5 & 6.77 & 975 & 1496 & 6.05 \\
\hline TC2011 & 21603 & 3244 & 4452 & 72.9 & 6.84 & 1074 & 1784 & 6.18 \\
\hline GC2011 & 27054 & 1915 & 2671 & 71.7 & 5.48 & 550 & 942 & 5.01 \\
\hline IC2011 & 23466 & 506 & 554 & 91.4 & 4.93 & 340 & 381 & 4.74 \\
\hline BS2010 & 6462 & 649 & 1133 & 57.3 & 4.70 & 434 & 711 & 4.45 \\
\hline GS2010 & 3837 & 1227 & 2036 & 60.3 & 6.39 & 1135 & 1938 & 6.35 \\
\hline BS2011a & 22323 & 3025 & 4297 & 70.4 & 6.37 & 872 & 1460 & 5.61 \\
\hline BS2011b & 17960 & 2676 & 3644 & 73.4 & 6.49 & 966 & 1733 & 5.91 \\
\hline TS2011a & 49755 & 4026 & 5556 & 72.5 & 6.19 & 748 & 1221 & 5.28 \\
\hline TS2011b & 20139 & 2092 & 2841 & 73.6 & 5.59 & 683 & 1045 & 5.00 \\
\hline IS2011a & 22047 & 2666 & 3507 & 76.0 & 6.55 & 897 & 1378 & 5.99 \\
\hline IS2011b & 47026 & 2637 & 2990 & 88.2 & 6.07 & 790 & 1332 & 5.50 \\
\hline GS2011 & 22893 & 1012 & 1365 & 74.1 & 4.31 & 357 & 510 & 4.00 \\
\hline
\end{tabular}

Abbreviation: OTU, operational taxonomic unit.

aThe sequence numbers of each sample were randomly normalized to 3400 using Selector.pl in Pangea. 


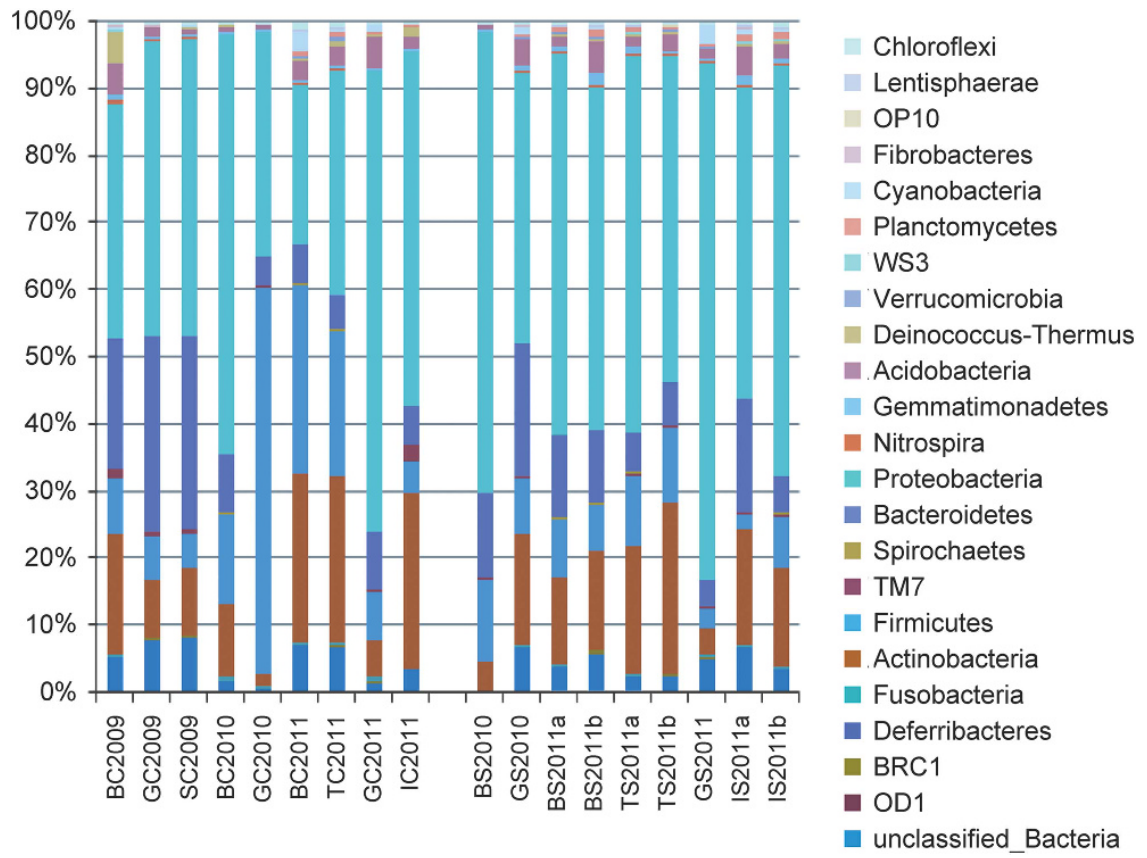

Figure 2 The relative composition of phyla of the sandstorm and control sand-associated bacterial populations. The samples on the left represent the sandassociated controls from non-sandstorm days, while those on the right represent sand-associated bacteria from sandstorm samples. See the Materials and methods for the naming scheme of the samples.

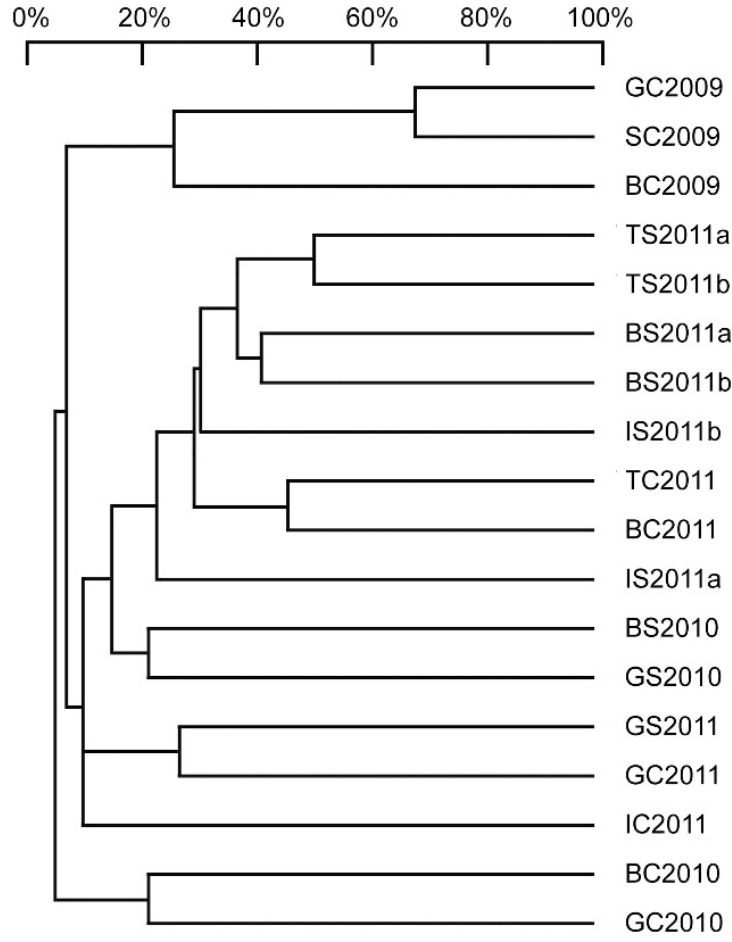

Figure 3 A UPGMA clustering tree of the sandstorm and control sandassociated bacterial populations using a Bray-Curtis similarity index $(97 \%$ cutoff) among samples, as described in the Materials and methods. Each sample was normalized to 3400 sequences.

be discussed later. We also detected OTU members from five genera (grouping members of the closely related Escherichia and Shigella genera) whose members were always proportionally reduced in sandstorm samples, versus the controls (Table 3).

\section{DISCUSSION}

Richness and diversity of sand-associated bacterial populations Increasing evidence has shown that the surface sands of Asian deserts, such as the Gobi and Taklamaken deserts, rather than being barren extreme environments, can contain diverse bacterial populations (An et al., 2013). It is thus not surprising that when desert soil is mobilized into the atmosphere, the concentrations of atmospheric sandassociated microorganisms can increase in the downwind regions (Griffin, 2007; Cao et al., 2014). Here, we explored the richness and diversity of sand-associated bacterial populations in gravity-collected sand (and dust) during sandstorms, as well as sterile sand-adsorbed local atmospheric bacteria, using pyrosequencing of PCR-amplified $16 \mathrm{~S}$ rDNA fragments from total DNA extracted from samples taken during Asian sandstorms, as well as controls (sterile sand-associated bacteria). We used gravity collection, as opposed to impactor or aspiration-mediated methods (Cao et al., 2014), in order to more accurately reflect environmental and human exposures to these particles. However, it is important to state here that the control samples will include both dust and sterile sand-associated bacteria, whereas sandstorm samples will include dust, transported sand and non-desert bacteria that adsorb to these during atmospheric transport. After trimming and removal of low-quality DNA sequences, we examined both total and sequence-normalized (3400 sequences) populations in order to make certain that sequence number differences were not markedly affecting our results (An et al., 2013).

\section{Bacterial population composition}

We sampled in Beijing and Gwangju each year from 2009 (only controls of sand-associated bacteria in the absence of a sandstorm) through to 2011 (sandstorm and control samples), with Incheon (South Korea) and Taiyuan (China) also sampled in 2011. As the PCA and UPGMA analyses showed, the samples did not appear to cluster by sampling site. These results suggest that variations in the structure of the sand-associated bacterial communities may be more influenced 
a

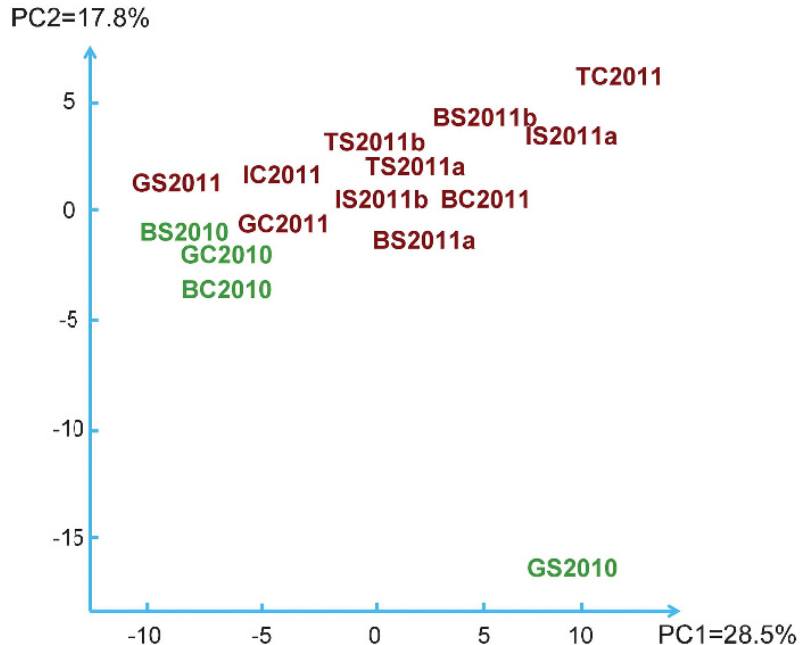

b

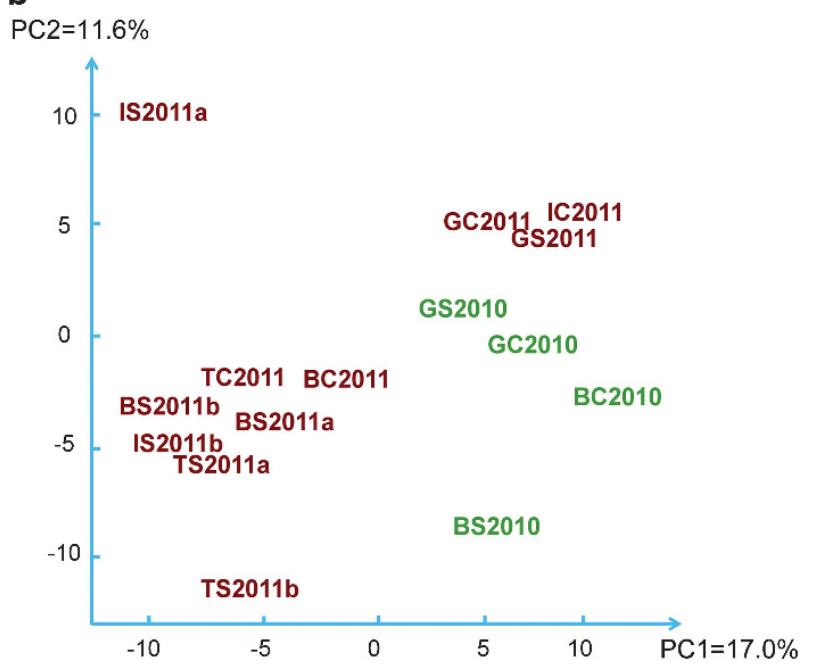

Figure 4 Normed PCA using phyla composition data (a) or OTU composition (b) data generated by R. Red letters are used to represent samples from 2011, whereas green letters are used to represent samples from 2010. See the Materials and methods for the naming scheme of the samples.

by time scale than by geographic proximity at the locations studied and are in agreement with other studies dealing with the annual variations in the diversity of atmospheric bacteria (Maron et al., 2005; Fahlgren et al., 2010). As the samples were clustered by their sampling year, we can hypothesize that an important variable in the differences in atmospheric bacterial populations may be due to changeability in the prevailing winds in each year (Cao et al., 2014). However, besides local meteorological conditions, the spatial variability of air-borne bacterial richness has been reported as being influenced by several different environmental factors, including land-use types and the distance from the sea (Bowers et al., 2011, 2012). The exception of the 2011 Gwangju sample may be due to the sampling time of the control sample, which was 4 days after the passage of sandstorm (see Table 1), suggesting that the effect of local atmospheric bacteria modifications of atmospheric particle-associated bacterial composition by sandstorms may remain for several days after the major event has passed.
Table 3 The sandstorm-associated bacterial genera increased or reduced, versus the controls, at each site in 2010/2011 (excluding the Gwangju 2011 sample)

\begin{tabular}{lccrcc}
\hline & Beijing & Gwangju & Beijing & Taiyuan & Incheon \\
& 2010 & 2010 & 2011 & 2011 & 2011 \\
\hline Increase in sandstorm & & & & & \\
$\quad$ Massilia & $6276 \%$ & $771 \%$ & $1434 \%$ & $89 \%$ & $2843 \%$ \\
$\quad$ Planococcus & $71 \%$ & $539 \%$ & $99 \%$ & $298 \%$ & - \\
Carnobacterium & $251 \%$ & $37 \%$ & $105 \%$ & $546 \%$ & - \\
Planomicrobium & $105 \%$ & - & $57 \%$ & $343 \%$ & - \\
Pontibacter & $2258 \%$ & - & $141 \%$ & $53 \%$ & $403 \%$ \\
Pedobacter & $1891 \%$ & $296 \%$ & $1514 \%$ & $205 \%$ & $1391 \%$ \\
Lysobacter & - & - & $97 \%$ & $85 \%$ & $88 \%$ \\
Sanguibacter & $179 \%$ & - & $55 \%$ & $634 \%$ & - \\
Ohtaekwangia & - & - & $268 \%$ & $579 \%$ & - \\
& & & & & \\
Decrease in sandstorm & & & & & \\
Escherichia, & $-69 \%$ & $-95 \%$ & $-56 \%$ & $-89 \%$ & $-97 \%$ \\
Shigella & & & & & \\
Acinetobacter & $-82 \%$ & $-32 \%$ & $-40 \%$ & $-37 \%$ & $-72 \%$ \\
$\quad$ Propionibacterium & $-100 \%$ & $-100 \%$ & $-45 \%$ & $-69 \%$ & $-91 \%$ \\
Corynebacterium & $-95 \%$ & $-85 \%$ & $-24 \%$ & $-40 \%$ & $-76 \%$ \\
$\quad$ Streptococcus & $-96 \%$ & $-96 \%$ & $-68 \%$ & $-67 \%$ & $-91 \%$ \\
\hline
\end{tabular}

— Indicates that members of the genus were non-detectable in non-sandstorm (control) samples.

\section{Dominant bacteria}

Previous studies, using mostly cultivation and/or DNA cloning and sequencing techniques, found that the predominant sand-associated bacterial groups in sandstorms were Gram-positive (such as members of the genus Bacillus) bacteria (Larsson et al., 1999; Lee et al., 2009), presumably because they can form desiccation and ultraviolet-resistant spores. Here, we found that Gram-negative bacteria, particularly members belonging to the phylum Proteobacteria, appear to be the predominant bacteria in particle-associated bacterial populations in the Asian sandstorm samples. In addition to the use of cultivationindependent DNA pyrosequencing of PCR-amplified 16S rDNA to assess the total bacterial populations, these differences may be due to differences in the sandstorm desert source bacterial populations (An et al., 2013; Prestel et al., 2013). As our samples could be grouped using UPGMA and PCA, it is likely that the origin of the sandstorms may be important in explaining the differences observed among different studies, in addition to wind sources and trajectories.

\section{Genus level population modifications}

Previous studies on the detection of bacteria in sandstorms did not always take into consideration the influence of locally present atmospheric bacteria in the absence of a sandstorm (Fahlgren et al., 2010). We thus obtained sand/dust-associated total DNA and analyzed the bacterial communities during both non-sandstorm and sandstorm days via DNA pyrosequencing and bioinformatics analyses. We found members from nine genera whose proportions increased in sandstorm event days (Table 3 ).

Members of the genus Massilia appear to be very abundant in sandstorm samples. However, they were not as readily abundant in the control samples, except for the Gwangju 2011 control sample, which was collected 4 days after a sandstorm. It is interesting to note that members belonging to the genus Massilia have been detected in desert environments (Chanal et al., 2006; An et al., 2013) and sandstorm samples (Griffin, 2007). That the detectable 16S rDNA sequences have 
$\geqslant 96 \%$ sequence similarity with that from the species Massilia timonae, isolated from patients (La Scola et al., 1998) and reported to cause wound infections (Van Craenenbroeck et al., 2011), suggests a potential Massilia infection risk for humans in Asian sandstorm downwind regions, although it should be emphasized here that most of the species belonging to the genus Massilia are not human pathogens.

Among the nine genera whose proportions increased during Asian sandstorms, members of the genera Pontibacter, Pedobacter and Lysobacter were also detected in the desert soils of China (Zhou et al., 2007; Tang et al., 2010; An et al., 2013), whereas members of the genus Planococcus have been isolated from African desert dust events (Griffin, 2007). These results suggest that members of these bacterial genera may be common in hot desert environments and subjected to atmospheric dispersal.

\section{Potential health threats}

In Seoul, increases of daily deaths due to Asian sandstorm events have been reported, especially for persons with advanced cardiovascular and respiratory disease (Kwon et al., 2002; Lee et al., 2007). In Taipei City of Taiwan, the rate of clinic visits for children increased $2.54 \%$ for preschool children and $5.03 \%$ for school-age children after Asian sandstorms (Chien et al., 2012). These results were often presumed to be due to dust mineral and chemical irritant/allergen penetration into the lungs. However, exposure to microbial and microbial-componentladen (lipopolysaccharide of Gram-negative cells) air-borne soils can also cause respiratory stress (Larsson et al., 1999).

After long-range transport, the diversity of bacteria deposited by sandstorms may have a significant role in ecosystem and human health and warrants further research in this emerging field (Hwang et al., 2005; Yang et al., 2005). In the future, more samples should be taken for spatial and temporal comparisons and studies should extend to the study of the domain of the Archeae, as well as eukaryotic microbes and viruses.

\section{DATA ARCHIVING}

All sequences data have been deposited in the MG-RAST database (http://metagenomics.anl.gov/metagenomics.cgi?page $=$ Home $)$ under number $4487160.3-4487161.3, \quad 4487162.3-4487166.3,4487168.3-$ 4487172.3, 4487174.3-4487177.3, 4487179.3-4487181.3.

\section{CONFLICT OF INTEREST}

The authors declare no conflict of interest.

\section{ACKNOWLEDGEMENTS}

We like to thank Barry Holland for interesting discussions and help with the manuscript, along with Cécile Couteau, Jimin Gwak and Fan Luo for technical assistance in the early stages of these experiments, and the Editor and anonymous Reviewers for their insightful comments and suggestions. This work was supported by the Centre National de la Recherche Scientifique (CNRS), France and by the AQUAPHAGE program of the Agence Nationale de la Recherche (ANR), France. Special Issue: Environmental Genomics

Amann RI, Ludwig W, Schleifer KH (1995). Phylogenetic identification and in situ detection of individual microbial cells without cultivation. Microbiol Rev 59: 143-169

An S, Couteau C, Luo F, Neveu J, DuBow MS (2013). Bacterial diversity of surface sand samples from the Gobi and Taklamaken deserts. Microb Ecol 66: 850-860.

Bell ML, Levy JK, Lin Z (2008). The effect of sandstorms and air pollution on causespecific hospital admissions in Taipei, Taiwan. Occup Environ Med 65: 104-111.
Bishop JK, Davis RE, Sherman JT (2002). Robotic observations of dust storm enhancement of carbon biomass in the North Pacific. Science 298: 817-821.

Bowers RM, McLetchie S, Knight R, Fierer N (2011). Spatial variability in airborne bacterial communities across land-use types and their relationship to the bacterial communities of potential source environments. ISME J 5: 601-612.

Bowers RM, McCubbin IB, Hallar AG, Fierer N (2012). Seasonal variability in airborne bacterial communities at a high-elevation site. Atmos Environ 50: 41-49.

Burrows SM, Butler T, Jockel P, Tost H, Kerkweg A, Poschl U et al. (2009). Bacteria in the global atmosphere - Part 2: Modeling of emissions and transport between different ecosystems. Atmos Chem Phys 9: 9281-9297.

Cao C, Jiang W, Wang B, Fang J, Lang J, Tian G et al. (2014). Inhalable microorganisms in Beijing's PM2.5 and PM10 pollutants during a severe smog event. Environ Sci Technol 48: 1499-1507.

Chanal A, Chapon V, Benzerara K, Barakat M, Christen R, Achouak W et al. (2006). The desert of Tataouine: an extreme environment that hosts a wide diversity of microorganisms and radiotolerant bacteria. Environ Microbio/ 8: 514-525.

Chessel D, Dufour AB, Thioulouse J (2004). The ade4 package-I: one-table methods. $R$ News 4: 5-10

Chien LC, Yang CH, Yu HL (2012). Estimated effects of Asian dust storms on spatiotemporal distributions of clinic visits for respiratory diseases in Taipei children (Taiwan). Environ Health Perspect 120: 1215-1220.

Choi DS, Park YK, Oh SK, Yoon HJ, Kim JC, Seo WJ et al. (1997). Distribution of airborne microorganisms in yellow sands of Korea. J Microbiol 35: 1-9.

Fahlgren C, Hagstrom A, Nilsson D, Zweifel UL (2010). Annual variations in the diversity, viability, and origin of airborne bacteria. Appl Environ Microbiol 76 3015-3025.

Giongo A, Crabb DB, Davis-Richardson AG, Chauliac D, Mobberley JM, Gano KA et al. (2010). PANGEA: pipeline for analysis of next generation amplicons. ISME J 4: 852-861.

Gorbushina AA, Kort R, Schulte A, Lazarus D, Schnetger B, Brumsack HJ et al. (2007). Life in Darwin's dust: intercontinental transport and survival of microbes in the nineteenth century. Environ Microbiol 9: 2911-2922.

Griffin DW, Kellogg CA, Garrison VH, Lisle JT, Borden TC, Shinn EA (2003). Atmospheric microbiology in the northern Caribbean during African dust events. Aerobiologia 19. $143-157$.

Griffin DW (2007). Atmospheric movement of microorganisms in clouds of desert dust and implications for human health. Clin Microbiol Rev 20: 459-477.

Hamady M, Walker JJ, Harris JK, Gold NJ, Knight R (2008). Error-correcting barcoded primers for pyrosequencing hundreds of samples in multiplex. Nat Methods 5: 235-237.

Hwang SS, Cho SH, Kwon HJ (2005). Effects of the severe Asian dust events on daily mortality during the spring of 2002, in Seoul, Korea. J Prev Med Public Health 38 197-202.

Iwasaka Y, Shi GY, Yamada M, Kobayashi F, Kakikawa M, Maki T et al. (2009). Mixture of Kosa (Asian dust) and bioaerosols detected in the atmosphere over the Kosa particles source regions with balloon-borne measurements: possibility of long-range transport. Air Qual Atmos Health 2: 29-38.

Jeon EM, Kim HJ, Jeong K, Kim JH, Kim MY, Kim YP et al. (2010). Impact of Asian dust events on airborne bacterial community assessed by molecular analyses. Atmos Environ 45: 4313-4321.

Kellogg CA, Griffin DW (2006). Aerobiology and the global transport of desert dust. Trends Ecol Evol 21: 638-644.

Kwon HJ, Cho SH, Chun Y, Lagarde F, Pershagen G. (2002). Effects of the Asian dust events on daily mortality in Seoul, Korea. Environ Res 90: 1-5.

La Scola B, Birtles RJ, Mallet MN, Raoult D (1998). Massilia timonae gen. nov., sp. nov., isolated from blood of an immunocompromised patient with cerebellar lesions. J Clin Microbiol 36: 2847-2852.

Larsson BM, Larsson K, Malmberg P, Palmberg L (1999). Gram positive bacteria induce IL-6 and IL-8 production in human alveolar macrophages and epithelial cells. Inflammation 23: 217-230.

Lee JT, Son JY, Cho YS (2007). A comparison of mortality related to urban air particles between periods with Asian dust days and without Asian dust days in Seoul, Korea, 2000-2004. Environ Res 105: 409-413.

Lee S, Choi B, Yi SM, Ko G (2009). Characterization of microbial community during Asian dust events in Korea. Sci Total Environ 407: 5308-5314.

Liu Z, Lozupone C, Hamady M, Bushman FD, Knight R (2007). Short pyrosequencing reads suffice for accurate microbial community analysis. Nucleic Acids Res 35: e120.

Maron PA, Lejona DPH, Carvalho E, Bizet K, Lemanceau P, Ranjard L et al. (2005). Assessing genetic structure and diversity of airborne bacterial communities by DNA fingerprinting and 16S rDNA clone library. Atmos Environ 39: 3687-3695.

Nishimura Y, Kenzaka T, Sueyoshi A, Li P, Fujiyama H, Baba T et al. (2010). Similarity of bacterial community structure between Asian dust and its sources determined by rRNA gene-targeted approaches. Microbes Environ 25: 22-27.

Prestel E, Regeard C, Salamitou S, Neveu J, DuBow MS (2013). The bacteria and bacteriophages from a Mesquite Flats site of the Death Valley desert. Antonie van Leeuwenhoek 103: 1329-1341.

Prospero JM (1999). Long-range transport of mineral dust in the global atmosphere: impact of African dust on the environment of the southeastern United States. Proc Natl Acad Sci USA 96: 3396-3403

Prospero JM, Lamb PJ (2003). African droughts and dust transport to the Caribbean climate change implications. Science 302: 1024-1027.

Shinn EA, Griffin DW, Seba DB (2003). Atmospheric transport of mold spores in clouds of desert dust. Arch Environ Health 58: 498-504. 
Tang Y, Wang Y, Ji S, Zhang K, Dai J, Zhang L et al. (2010). Pedobacter xinjiangensis sp. nov., from desert, Xinjiang. J Microbiol Biotechnol 20: 397-402.

Tolias PP, DuBow MS (1986). The overproduction and characterization of the bacteriophage Mu regulatory DNA-binding protein Ner. Virol 148: 298-311.

Van Craenenbroeck AH, Camps K, Zachee P, Wu KL (2011). Massilia timonae infection presenting as generalized lymphadenopathy in a man returning to Belgium from Nigeria. J Clin Microbiol 49: 2763-2765.
Wang Q, Garrity GM, Tiedje JM, Cole JR (2007). Naive Bayesian classifier for rapid assignment of rRNA sequences into the new bacterial taxonomy. App/ Environ Microbiol 73: 5261-5267.

Yang CY, Tsai SS, Chang CC, Ho SC (2005). Effects of Asian dust storm events on daily admissions for asthma in Taipei, Taiwan. Inhal Toxicol 17: 817-821.

Zhou Y, Wang X, Liu H, Zhang KY, Zhang YQ, Lai R et al. (2007). Pontibacter akesuensis sp. nov., isolated from a desert soil in China. Int J Syst Evol Microbiol 57: 321-325. 